\title{
Religion of the Selkups and the Kets in the Historical and Cultural Genesis
}

\author{
Yuliya N. Avdeeva, Kseniya A. Degtyarenko, \\ Daria S. Pchelkina, Kseniya I. Shimanskaya, \\ Natalia P. Koptseva and Anna A. Shpak* \\ Siberian Federal University \\ 79 Svobodny, Krasnoyarsk, 660041, Russia
}

Received 06.11.2018, received in revised form 30.04.2019, accepted 08.05.2019

The article is devoted to the study of the genesis of religious ideas of the Ket and Selkup ethnocultural groups in a historical and cultural context. On the basis of the ethnographic and linguistic material, the article describes the current state of religion and culture of the Kets and Selkups, provides an analytical review of classical and modern studies reflecting the dynamics of the development of religious ideology in the territories inhabited by these ethnic groups. Despite the official Christianization, both the Kets and the Selkups have retained their traditional cosmological and ideological views for many years. Their religious ideology is characterized by coexistence of beliefs and rites of different origins and specificities that reflect natural, everyday, economic and social conditions of ethnic communities. The key manifestations of religious ideology include the idea of the three-part structure of the universe, animistic and ancient totemic beliefs, developed trade ideology, shamanism, burial rites and folklore.

Keywords: Kets, Selkups, indigenous peoples of the north, religion, religious cults, shamanism, trade ideology, animism, totemism.

The reported study was funded by JSC "Vostsibneftegaz" according to the research project: "Revival of the Evenk's Language: Creation of the first Evenks digital audio library".

Research area: culturology.

Citation: Avdeeva, Yu.N., Degtyarenko, K.A., Pchelkina, D.S., Shimanskaya, K.I., Koptseva, N.P., Shpak, A.A. (2019). Religion of the Selkups and the Kets in the historical and cultural genesis. J. Sib. Fed. Univ. Humanit. soc. sci., 12(5), 726-751. DOI: 10.17516/1997-1370 0419.

(C) Siberian Federal University. All rights reserved

* Corresponding author E-mail address: annaheyy@gmail.com ORCID: 0000-0003-3910-7991 (Koptseva)

This work is licensed under a Creative Commons Attribution-NonCommercial 4.0 International License (CC BY-NC 4.0). 


\section{Religion of the Selkups in cultural and historical genesis}

The ethnonym "Selkup", which means "forest, taiga people" in the Selkup language, was officially entrenched for the Selkup ethnic group in the 30's of the twentieth century. Until that time, the people were called Ostyak-Samoyeds.

According to the 2010 census, the Selkups reside in the following territories in Russia: Tyumen Region (2065 people), Yamalo-Nenets Autonomous District (1988 people), Tomsk Region (1181 people) and Krasnoyarsk Territory (281 people). And their total population is 3,649 people. It is worth noting a significant decrease in the number of Selkups compared to the 2002 census.

The Selkup language belongs to the Samoyed branch of the Uralic language family and has six dialects and two talks (Koptseva, 2012). Writing was developed in the 1930 's of the twentieth century, first on the Latin, then on the Russian graphic basis. A great contribution to the development of the Selkup writing and the creation of the first literature in the Selkup language belongs to E.D. Prokof'eva. According to the data of 2010, $60.5 \%$ Selkup indicated Russian as their mother tongue, and $36.5 \%$ indicated the Selkup language.

The modern Selkups are represented by two groups - northern and southern groups, the division into which occurred in the $17^{\text {th }}$ century. Northern Selkups live in the east of the Yamalo-Nenets Autonomous District (Krasnoselkupsky District), in the Tyumen Region and in the north of the Krasnoyarsk Territory (Turukhansky District). Southern Selkups reside in the north of the Tomsk Region (Kolpashevsky District, north of Parabelsky and Kargasoksky districts). The differentiation of the Selkups into two groups is due to the territorial disunity, the differences in dialects and, in general, the formation of the characteristics of the cultures of these two groups. The Northern Selkups are in contact with the North Samoyed peoples, Evenks, Kets - and they managed to keep the traditional trade economy, the traditional way of life (living in compact settlements, reindeer herding, chum, clothing, food, utensils, etc.); traditional religious attitudes, ritual practices continue to be relevant for this group of the Selkups (Vlasova, 2009). The Southern Selkups, however, have great assimilation with the Russian population, in connection with which they have lost many elements of the traditional Selkup culture. But, despite this, such researchers as G.N. Prokof'ev (Prokof'ev, 1940) and E.D. Prokof'eva (Prokof'eva, 1952), G.I. Pelikh (Pelikh, 1972), who have studied the Selkup, talk about the unity of culture and the origin of the northern and southern groups of the Selkups. 
The emergence and formation of the Selkup identity is associated with the period of the end of the $1^{\text {st }}$ millennium $\mathrm{BC}$ - the middle of $1^{\text {st }}$ millennium AD. And the territory of Narym and Tomsk Ob Region is native. At that time, the Selkups were descendants of the Rölkin culture (Chindina, 1991), which in turn is the successor to the Kulay culture of the Middle Ob Region (Mogilnikov, 1929). The researchers note that the elements of the lifestyle, tools of labor and life have similar features with the ethnographic material of the Selkup culture.

The first mentions in written sources about the Selkups belong to the $16^{\text {th }}$ century in connection with the so-called "Skewbald Horde", which included about 400 soldiers. In the next century, the Selkups are divided into northern and southern groups. Cultural and economic differentiation is taking place among the Southern Selkups. And the northern Selkups leave the Ob lands to the north, to the areas of the Taz, Kureika, Turukhan and their tributaries. By the second half of the $17^{\text {th }}$ - the first half of the $18^{\text {th }}$ centuries, they master reindeer herding, and their way of life becomes more mobile. By the second half of the $18^{\text {th }}$ century the Selkups begin to adopt the culture of the former inhabitants of this area - the Khanty, Kets, Evenki — and become one of the dominant groups in the area. The Southern Selkups are assimilated with the cultures of the Tomsk Tatars and Russians. By the end of the century, the Christianization of the predominantly Southern Selkups is completed, while the Northern ones retain traditional beliefs.

The works of N.S. Rosov are devoted to the study of the anthropogenesis of the Selkups living on Middle Ob Region (Rosov, 1958). Iu. B. Simchenko explores and systematizes the generic banners, signs (tamgas) of the indigenous peoples of Siberia, including the Kets and Selkups tamgas, based on the analysis of the ethnogenesis of peoples, clan composition, social relations and types of community (Simchenko, 1965). M.S. Batashev and N.P. Makarov are exploring the aspect of the mutual influence of the peoples of the North and the Russian population within the framework of the cultural genesis of the peoples of the North of the Krasnoyarsk Territory (Batashev, Makarov, 2018).

In addition to the study of language and culture, social organization, traditional types of economic activity, E.D. Prokof'eva made great contribution to the study of traditional religion of the Selkups (Prokof'eva, 1949; 1976; 1977). G.I. Pelikh also dealt with the problem of the spiritual culture of the Selkups (Pelikh, 1972; 1980). I.N. Gemuev (Gemuev, 1980), A.V. Golovnev (Golovnev, 1995); I.V. Belich (Belich, 1997) and others studied traditional beliefs, religious cults of the Selkups. Such 
researchers as A. Baulo (2018), O. Kazakevich (Kazakevich, 2018), Iu.L. Ozhereredov, A. Iu. Ozhedredova and S. Kulizhskii (Ozheredov, Ozheredova, Kulizhskii, 2014) study elements of religious practices and come to the conclusion that the tradition of metaphorical perception of nature is preserved in the modern Selkups, and that there is a need to maintain a close relationship between man and nature as the basis of balance in the world.

A linguistic direction in the study of the traditional beliefs of the Selkups was revealed. A linguo-culturological analysis of the Selkup mythology was carried out by A. A. Kim-Maloni and A.V. Tereshchenko (Kim-Maloni, Tereshchenko, 2018), whose research was based on a review of the Selkup images of the shaman's journey and, as a result, made it possible to obtain a partial reconstruction of the world picture of the Selkup people. Also, the reconstruction of fragments of the Selkup ethnic picture of the world, using the method of interpretive anthropology, is being carried out by such researchers as O.M. Ryndina, S. Iu. Kolesnikova, V.M. Kulemzin (Ryndina, Kolesnikova, Kulemzin, 2018). Linguistic studies of the Selkup folklore confirm the presence of anthropomorphism in the culture of the ethnic group (Kim, 2018). The study of shamanistic legends in the Selkup folklore was made by N.A. Tuchkova (Tuchkova, 2018) and A.V. Tereshchenko (Tereshchenko, 2014).

N.V. Toroshchina, A.L. Bobrova and M.B. Shatilov (Toroshchina, Bobrova, Shatilov, 2015), Iu.L. Ozhereredov, A. Iu. Ozhedredova and S. N. Kirpotin (Ozheredov, Ozheredova, Kirpotin, 2015), L.V. Pankratova (Pankratova, 2011) explore burial rites and ritual processes in the context of ritual elements and the making of idols. Scientists carry out classification and ethnographic interpretation of wooden, bronze idols and tin masks.

The basic ethnographic data on the culture of the Selkups, which began to actively accumulate with the beginning of the twentieth century, makes it possible to trace the origins of the religious beliefs of the people and to determine the specificity of the religion of the Selkups today.

Formally, the Christianization of the Selkups took place in the $17^{\text {th }}-18^{\text {th }}$ centuries and had the consequences of including some Christian ideas in the religious ideas of the Selkups, for example, highlighting the supreme deity, the activities of demiurges, the formation of concepts of sin, soul, or exaltation of crosses at a burial site, etc. However, the people retained pantheistic ideas about the surrounding world, in particular the Northern group of the Selkups. This article explores the traditional cosmogonic and ideological views of the Selkups, as well as their ritual practices. 
The Selkups share a common idea of the three-part structure of the universe with the unity of the Upper, Middle, and Lower Worlds (Poliakova, 2015). In the vertical picture of the world, the Upper world is manifested by the sky, the Middle one - by the earth, the Lower world is under the earth. In the horizontal picture of the world, characteristic of the Selkups living along the banks of the rivers, the Upper World is associated with the headwater, a source of the river and is located in the south, the Medium World is with a middle course of the river and a place where a specific group of people lives, and it is located in the north (Pelikh, 1972). Both the earth and the sky, in turn, were not one-dimensional spaces. The earth is seven-layered, with levels extending downward and westward, and each of the seven levels is illuminated by its sun. The sky in the Selkup worldview has a nine-part structure (Poliakova, 2015). Each of the worlds is inhabited by the respective inhabitants: the Upper World — by the highest deities, the Middle World — by people and animals, the Lower World is inhabited by the dead and the spirits. Moreover, among the Selkups, like many ethnic groups, the sky is ruled by the creator and the good beginning Nop or Nom (Num) (it is abstract and inaccessible to humans, it is not addressed with prayer, as K. Donner notes). The Lower World is inhabited by the evil ruler - Kyzy. But life on earth was subordinated to the Old Woman of Life (the Worldly Woman).

According to the Selkups, the three worlds are not isolated from each other, they are not only penetrated by the river and the world tree, but there is also a kind of a "pass-entry" system represented by entries, loopholes, holes from the Lower world to the Middle world. Such a portal for moving between worlds could be, for example, a funnel on the water. And the entry from the Lower World to the Middle one is guarded by a mammoth.

It was believed that the gods and a shaman have god-helpers or satellites called "lozy". Kyzy had many such "lozy" that had the ability to penetrate into a body through a skin, thereby causing illness, eating one or another organ. The task of the shaman is to drive the spirit out of the body of a patient. The "lozy" of the shaman drove the evil "lozy" out of a person to the surface of the body. With the death of a person, the evil lozy do not die, but "go with the wind" and penetrate into another person. The reason for the illness of a person could be the abduction by evil spirits of one of his souls, then the shaman would go in search of this soul. If the search was completed successfully, the person would recover, if it was unsuccessful - the person would die.

Anthropogonical representations of the Selkups are associated with several versions. Firstly, it is a general and territorially widespread idea of the origin of a man 
through the creation of Nom who created the universe and everything in it. Secondly, it is a more specific idea based on the myth about the origin of the Selkups from the Selkup land itself - a man got out of the moss and grass to the outside (Baidak, 2010).

It should be noted that each genus possessed a generic totem animal - took its origin from any animal or bird that became sacred (Sidorova, 2017). E.D. Prokof'eva also proves the origin of the Selkup clans from animals whose ancestor was the mother animal (Prokof'eva, 1952).

The traditional way of life, the nature of the commercial and economic activities of the indigenous peoples, including the Selkups, is directly reflected in the mythology, folklore, when it comes to the forces of nature, the importance and significance of fire, the image of a tree in the culture of the Selkups, the organizing role of the river in the structure of the universe about the wind as a conductor between worlds. The Selkups' view of the world as a whole is pantheistic, so the Selkups fill the world around them with spirits or gods. Natural elements become personified, for example, the fire is personified into the Mistress of Fire, they participate in all processes of the circle of life.

E.D. Prokof'eva notes the presence of the Selkup preshamanic cults. Among them there is a cult of fire that is functionally similar to the cult of fire in the Ket culture, with which the Selkup unite a number of prohibitions associated with this cult. Fire as a phenomenon is represented by the Selkups as a living being, and like all living things in nature, it goes through the "birth-death-birth" cycle. It is endowed with speech and the ability to speak in bird voices. There is a sacred meaning in fire; therefore a regulatory system in the form of prohibitions and rules has been developed for it. Smoke from the fire permeates the underground, earthly and upper worlds and is one of the elements connecting the structure of the world, like a tree, a river, a mountain. Smoke acts as a participant in the organization of communication with the spirits of the deceased ancestors - it was used in funeral and memorial practices (Poliakova, 2016).

If we turn to the water element, then in the Selkup mythology it is the image of a river that is important, not the water itself. The river, as was said earlier, is an element connecting the three worlds, a kind of axis on which the other worlds are strung. The burials were organized in accordance with the flow of the river. The value of water for the life of the indigenous peoples is high, the value in the cosmological aspect is respectively high too. The surface of the river is perceived as the boundary of the Middle and Lower worlds, and a swirl — as a portal between the worlds of the dead and the living. 
The element of wind, as well as the fiery element, is a conductor between the worlds. Present in all the worlds, the wind helps folk heroes to transport from the real world to the Upper one.

In everyday life, each Selkup had a double-puppet — "kulaga" that they always carried with them during migrations, and when they got married they took them with them. After the death of the owner, they were burned or carried to the forest (Bobrova, Toroshchina, 2013). The presence of such a religious object indicates the existence of a cult of the guardians of the family and clan among the Selkups.

Among the preshamanistic beliefs, there is also a cult of sacred places, the ritual acts of which are also similar to the Ket ones.

The forest is not only the main location of the Selkups, but also the habitat of mythical creatures, which is reflected in folklore. The forest is inhabited by spirits and gods - the Selkups believed in the forest host spirit (machil-lozy), etc. The spirits of the forest, as well as aquatic spirits must be offered sacrifices to ensure success in the trade. As the main place of residence, the forest serves as a guide for the Selkups. There is "own taiga" located on the back of the mother-earth, and the rest is "another taiga" - the taiga of relative distance or proximity to the settlement.

The image of a tree is one of the most significant symbols for the Selkup culture. Firstly, it is connected with cosmogonic ideas - there is a concept of the World Tree "Daru", which, along with the river, is the axis of the universe in the Selkup mythology. The idea of a tree as the axis of the universe has developed thanks to its three-part structure: the roots are in the Lower world, the trunk is in the Middle world, and the branch ends are in the Upper world, so the tree is present in each of the worlds. Its roots reach the fiery layers of the Underworld, fire feeds its roots, and fireballs-suns grow on the branches instead of fruits, illuminating the seven layers of the earth. And every day one of them lights up the sky, and then falls back into the fiery underworld (Stepanova, 2007). Secondly, various types of trees became part of certain rites, and the corresponding meaning was assigned to them. Thus, the Selkups made cedar decorations for funeral rites, so cedar became the personification of the world of the dead. On the contrary, birch personifies birth and life, protecting the Middle World from the Lower one. A rowan drove away the spirits (Surkov, 2012). The stars, according to the Selkups, are the ends of the roots of trees growing in the Upper world (Prokof'eva, 1976).

The main zoomorphic images of sacred significance are a bird, a mammoth and a bear, who participated in maintaining the balance between the worlds, guarding them or 
helping a shaman. Birds were particularly important because they could move between worlds. Thus, the eagles are representatives of the Upper world and the assistants of the shamans (Prokof'eva, 1976), and a loon has got land from the bottom of the primary ocean. And a human soul ("syumesh" or "il") has the shape of a bird with a human face.

The image of a mammoth is associated with the protection of the underworld, namely the entry from the Middle world to the underground, and patronage of a shaman, its figure is one of the attributes of the shaman's breastplate (Baulo, 2018). The mammoth in myths is represented by such creatures as a mammoth-pike, a mammothbear.

A bear in the Selkup mythology is a sacred animal - in the monograph written by V.A. Muitueva it is noted that in order to avoid punishment for killing a bear, hunters perform rites and adhere to prohibitions. However, in the case of a bear eating a person, it is considered a cannibal, and in order to free a human soul from the body of a bear, a holiday and a ritual eating of a bear's heart are held.

As in the culture of other indigenous northern peoples, the Selkups placed special emphasis on a funeral rite based on the specificity of their fishing activity.

First of all, it is worth noting that death did not have a negative connotation for the Selkups - death is perceived as continuation of life and predestination from above. Death as such does not exist, only a transition to another world. Life expectancy in the Selkup representation is measured by Nom. If a person did not die at an old age, it was believed that the spirits of ancestors, relatives called this person at that moment to continue life in another world. The transition to the world of spirits does not occur immediately after the moment of death, but takes about 2-3 days, and during this time a soul is in the places that it has visited during its life. It is possible to trace the commonness of the Christian and archaic ideas about the soul as something providing a cyclical life.

Based on ethnographic studies, it can be concluded that in ancient times the Selkups practiced the ritual of air burial (Prokof'eva, 1977; Pelikh, 1998; Gemuev, Pelikh, 1993). Children were buried on the branches of tall trees, and adults were tied with straps to tree trunks or buried in hollowed tree trunks (less often in the ground), the body of a deceased was wrapped with animal skins. However, later the rite underwent changes and became associated with the water element: the body of a deceased floated down the river to the mouth in a cedar boat after the funeral. In the right wall of the boat-coffin, they would make a hole for a shaman to communicate with the dead. Later, the third 
element was used in the funeral rite - land: the Selkups were buried in the ground, but the coffin was still a boat made from a cedar, and it was so narrow, the body could barely fit in it (Pelikh, 1972).

The structure of the world of the dead includes the way to the Lower world, down and to the west. In the world of the dead there may be different nations. The underworld has a mistress - Kvendygai Paya, she was the first one who died (Baulo, Tuchkova, 2017). It was believed that, in the world of the dead, people are engaged in the same economic affairs as in the Middle world. Like many other ancient cultures, the deceased were buried with their property, considering that things would be useful to them. However, the world of spirits is different from the world of the living; therefore, the form and appearance of things would differ in these two worlds, thus, things were subjected to deterioration before being placed in the grave and coffin. For example, clothes were cut at the seams, some elements were torn off, a sole of a shoe was ruined, and blades or eyes of needles were broken.

The study of the Selkup religion is impossible without resorting to such a figure of the Selkup ritual cults as a shaman. Shaman occupied and occupies a special place in the hierarchy, like other Arctic peoples. The shamanic gift of the Selkups is considered to be necessarily inherited (Tsai, Rusak, Efanova, 2016). The functions of the shaman were diverse - he could predict events, return souls of ill people back to the Middle World, communicate with spirits of various kinds, be a guide between all the worlds.

The integral attributes of any shaman are a tambourine and a beater. The beater is used not only for kamlanie (shamanic ritual), but also for fortune-telling by the nature of its fall: the shaman threw it up holding it at the top. If it fell with the nap up, the shaman could not proceed to the kamlanie, if the nap was down, he could begin (Galeeva, 2016). One of the original rituals in the Selkup shamanism was a ceremony of "reviving" the tambourine and other items of shaman vestments.

The shaman's breastplate replicates the three-part structure of the universe. The shaman's specialization is recognized by the image and location of the sun in one or another part of the Lower, Middle or Upper World. In the upper part of the breastplate there are zoomorphic figures that are the supreme spirit of the shaman. Also in the garment there are long pendants personifying worms, which are designed to fight the worms of the Middle World, they personify evil spirits. In the zone of the Lower World figures of salt marks can be placed. Salt marks are mounted on the key bone of a deer. The mammoth can be found on a dress of the shaman as a receptacle of a spirit myrak (Baulo, 2018). The elements of the breastplate must be made of metal, and the 
type of metal has its symbolic meaning. Copper personifies the Middle World, as it is similar in colour to human skin; iron is a symbol of the underworld.

The rite of burial of shamans is different from the funeral of an ordinary member of the community. The ceremony included the burial of the physical and mental components. A body of the dead shaman is wrapped in leather or bark, tied with straps, seated in a hole, and things are buried in a separate hole. Also people made a doll-container for his soul, which was also buried. The doll could either be burned or hung on a tree.

Thus, the Selkup religion is based on traditional beliefs based on animistic and totemistic ideas, partially preserved to the present, which were later joined by shamanism. Today we can note a certain syncretism inherent in the Selkup religion, which reflects the pre-shamanistic cults, shamanism, Christianity and some features of the religion of the neighboring ethnic groups.

\section{Religion of the Kets in the cultural and historical genesis}

The ethnonym "Kets" — translated as "a man" — was introduced in the 1920's. Until that time, the Kets were called Ostyaks, Yeniseans, or Yenisei Ostyaks. The Kets live mainly in rural areas on the territory of the Krasnoyarsk Territory and Tomsk Region. In the villages of Kellog, Sulomai and Maduikaket their population is predominant.

The highest population rate of the Kets was recorded in the official census of 2002. In 2010, 1,219 Kets were recorded, and this is the second result in the number of representatives of this group of indigenous peoples in the history of official censuses, which, in addition to 2002 and 2010, were conducted in 1959, 1970, 1979 and 1989.

The Ket language is considered as one of the last representatives of the Yenisei language family. The language has a northern, central and southern dialects, the latter in turn is divided into talks. Despite the existence of a Latin-based alphabet since the 1930's, the emergence of a really functioning alphabet is associated with the 1980's, when a primer of the Ket language was issued for the first grade at schools, thus, teaching of the Ket language as an academic discipline began. The new alphabet was developed on the basis of the Cyrillic alphabet with the addition of special symbols. However, there is a problem of preserving the Ket language — outside the academic environment native speakers did often not use it, and already in 1989 almost half of the Kets called Russian to be their native language.

Studies of the Ket language and culture are reflected in the works of A.P. Dul'zon (Dul'zon, 1968), E.A. Alekseenko (Alekseenko, 1967), G.K. Verner (Verner, Nikolaeva, 
1993), O.A. Kazakevich and E.A. Helimskii (Kazakevich, Helimskii, 1994), E. A. Kreynovich (Kreynovich, 1968) and others. The great role in the study of Ket history and ethnography belongs to the Soviet researcher of the peoples of the North B.O. Dolgikh (Dolgikh, 1934). The work of R.V. Nikolaev is devoted to the study of shamanism in the Ket mythology (Nikolaev, 1985).

The history of the origin of the Kets as an independent people is a complex process of interaction between different peoples and groups over a long period of time. Scientists agreed that the Kets originated from the carriers of the Bronze Age cultures in the south of the $\mathrm{Ob}$ and Yenisei rivers: the Kets arose from the mixture of ancient Mongloids with the Europoids of Southern Siberia. Like most ancient peoples, the Kets were divided into smaller groups, some of which assimilated with other peoples (for example, Russians, Turks, Evenks, etc.), the other part of the Kets moved to more northern territories or eastern lands. The relocation to a new territory of residence took place approximately in the $9^{\text {th }}-13^{\text {th }}$ centuries, at that time the Kets contacted with the ancestors of the Selkups and the Khanty. And at the same time, the formation of a distinctive Ket culture occurred. And the relocation to the north, to the Turukhan and Kureyka rivers, happened in the $18^{\text {th }}$ - early $19^{\text {th }}$ centuries.

For the first time, shamanism and the Ket religious beliefs became an object of the study at the beginning of the $20^{\text {th }}$ century. One of the most famous works devoted to the study of the religious beliefs and shamanism of the Kets is the monograph titled "An Essay on Shamanism among the Yenisei Ostyaks" by V.I. Anuchin, who for several years (1905-1908) collected ethnographic, anthropological and linguistic material in the North Turukhansk (Anuchin, 1914). Anuchin collected an extensive subject and illustrative material on the material and spiritual culture of the Kets, recorded over 20 rolls of phonograms with shamanic songs that remain untranslated and unexplored. Items collected by V.I. Anuchin entered the exposition of the Museum of Anthropology and Ethnography named after Peter the Great.

Following him, in 1912, during a three-year stay (1911-1913) in Central Siberia, a Finnish linguist and ethnographer C. Donner visited the Kets (Donner, 1933). The materials of his research include the Ket folklore works - several tales, short stories, 34 riddles, a Ket dictionary. They were published by A.I. Ioki mainly posthumously (Ioki, 1946). Donner's materials also contain valuable information from a Ket I.F. Dibikov and are supplemented by personal observations and linguistic data collected during a trip to the Yenisei. Mythology and folklore are of great importance for the study of the Kets' religious consciousness, the collection, publication and development of which 
are associated with the names of A.P. Dul'zon (Dul'zon, 1968), E.A. Kreynovich (Kreynovich, 1968), V.N. Toporov and B. A. Uspenskii (Toporov, Uspenskii, 1968).

The main interest of N.K. Karger (Karger, 1934) and H. Findeisen (Findeisen, 1937) was shamanism. Karger collected a subject, illustrative and phonographic material on the territory of the Turukhansk Region in 1928. He became the author of the first $\mathrm{ABC}$ book (in Latin) and an essay on grammar, the collector of a valuable ethnographic collection for the Museum of Anthropology and Ethnography. Findeisen collected a huge amount of material, including songs, photographs and artefacts. Some of the data obtained by him are known from the monograph written in 1953, the rest is unpublished or lost in the Second World War.

The works by S.I. Vainshtein written in the 1940-1950's (Vainshtein, 1951; Vainshtein, 2015) contain valuable information about the Ket culture, including rare drawings and photographs of the author, and to date have not lost their scientific value.

New extensive data were obtained as a result of collecting field material in 19701972, the main informants in the years of the field work were the Kets of old age from different local groups, whose close relatives were shamans. A special role is to be taken by E.A. Alekseenko (Alekseenko, 1967; Alekseenko, 1981; Alekseenko, 1984), who has devoted three decades to the study of folklore, ethnogenesis and the history of the traditional Kets culture.

The Kets were considered to be the ones who officially accepted Christianity, but by the beginning of the $20^{\text {th }}$ century, ancient religions and beliefs were the basis of their religion. The penetration of Christianity was quite superficial and boiled down to the formal performance of Orthodox rites among a certain part of the Ket population during fairs. Most of all it affected those representatives of the Ket ethnic community who constantly lived in Russian villages or in their immediate vicinity. Under the influence of the Orthodox trends the Kets began to place crosses on graves, keep crosses and icons with other sacred things, and variations of biblical legends (about the Tower of Babel, the Flood, etc.) emerged. Also, the Kets had an idea about the afterlife, the existence of the supreme deity (similar to the Christian god). Despite this, Christianity did not touch the depths of the Ket religious ideology.

The religious ideology of the Kets is the simultaneous existence of beliefs and rituals of different origins and specificities. Often with different genetic roots, they served one specific goal, namely ensuring success in economic and commercial activities. The powerlessness of a man in front of natural phenomena, illness and death also found reflection in religion. 
A manifestation of social psychology of the clan organization is characteristic for some religious ideas: a sense of interconnection and solidarity of the representatives of the ethnic community. A clan group, a family (and its individual members) played a key role in the performance of the rites.

Basically, religious beliefs are animistic. The surrounding world was inhabited by various supernatural beings that live in close proximity to man and enter into various relationships with him. The nature of the relationship of these creatures with man divides them into several categories - some are more neutral towards man (numerous "stone", "earthly" and "heavenly" people); others were extremely important - the success of hunting or fishing depended on them, they were tried to appease (for example, Kaigus is the owner of all animals; Kholai is the patroness of all prey); the third were hostile to oppose them people turned to the ritual practices.

Various natural elements (wind, rain, thunder) also acted as animistic images. And the formation of some mythological images is also genetically related to the phenomena of nature. For example, the main Kets deity, the creative beginning, is an old man with a beard called Es, who lives in the sky and, in fact, personifies it. Religious ministers and ordinary people also turned to him for help. And under the patronage of the hostess of the night Khosedam, who lived in the north, there are evil spirits. If the souls of people get to it and the shaman cannot free them, people die.

The relics of the ancient totemic notions had a special place in the Kets religious ideology, which is observed in shamanism and the basis of many fishery beliefs. Some mythological images and plots can be associated with the idea of totemic ancestors (Kaigus is the son of a bear and a woman; scenes about the connection between a man and a sable, a woman and a bear, etc.).

The Kets worshiped supernatural beings, protectors and patrons of animals, fish and birds. These images were represented as owners of water and forest lands (Kaigus is the owner of all forest animals; Ulgys is the owner of water areas, etc.); family and ancestral shrines (fire; alely — anthropomorphic female figurines; stones of unusual shape as fetishes; dangols - images of people who died in suffer or were distinguished during their lifetime by participation in the supernatural).

As was mentioned earlier, the specificity of the Ket religious ideology is based on fishing activity. Commercial beliefs are reflected in various prohibitions and rules of fishing activities, rites and signs, which in turn were the result of observing the life of animals and nature, as well as specific trade ethics. 
Most of the Kets' fishing beliefs are associated with the assimilation of animals to man - with the ability of animals to understand human language, in a similar way to perceive the world around. In this regard, there are various prohibitions and precautions: to talk about the upcoming fishery; to talk loudly in the taiga; women were forbidden to step over weapons, reindeer harnesses and sit on a male sled; to talk badly about animals, cause them suffering, make fun of them and kill more than what is permitted (it was believed that animals could take revenge on man). Fishery success was facilitated by various magical actions on the fishing gear: people fumigated it with a smouldering shred of deerskin, soaked objects in special solutions, etc. the Kets believed in the possibility of transferring the specific qualities of an animal to humans, and some prescriptions arose regarding eating one animal or another: in order to acquire power, you had to drink blood or eat a piece of the heart of a freshly dressed bear, etc. Various ritual actions and orders of the Kets are associated with ideas about the revival of harvested animals. In accordance with these ideas there was a prohibition to cut and throw away the main parts of the skeleton of animals. The idea of rebirth reflected the desire of man to provide himself with food for the future.

Turning to the Ket shamanism, it is worth noting that not all issues relating to the Kets' religious consciousness and shamanism are provided with material - most of the information is fragmentary and sometimes even contradictory. For example, the word "shaman" is represented in the Ket language in two variations: senin and kuttyn. There are several categories of Ket shamans, distinguished by their functions, semantics of appearance, attributes, and ideas about the sphere of activity (they distinguish the first, "lower" - the earthly world, and the second, "upper" - the sacral world).

Religious worshipers were not sharply separated from the rest of the Kets. Shamans could be both men and women, but the former prevailed. Women because of their "uncleanness" could not reach the level of a great shaman, their activity was limited to the earthly sphere (according to other data, they could rise to the sacred upper world, but only until its first circle). Shamanism was hereditary (transmission on a paternal side only within one exogamous collective). The shaman's gift was revealed by a hereditary disease, which manifested itself during puberty and had features of mental disorder. The very concept of "shaman's gift" received several interpretations, and among them, until the beginning of the $20^{\text {th }}$ century, the most common were: 1 ) a gift — a human-like kut; 2) a gift — special "heavenly people" (esden). The shamanic gift was recognized as eternal, and its bearers (shamans) represented only temporary links in the common, endless chain of its existence. The emergence of a new shaman 
is due to the attainment of the shaman's gift by the chosen one and passing of a certain test, thanks to which a person proved his ability to be a shaman.

A shaman of the Kets was the personification of a bird and, according to the legends, the first shaman was a two-headed eagle (he taught people to shaman, for which he lost his second head). Those shamans who showed their involvement in shamanism in the springtime (with the arrival of birds) had a special power.

The basis of shamanism was the idea of the shaman's ability to act as an intermediary between man and the supernatural world. By his actions, the shaman depicted a journey between the worlds and the struggle with the evil spirits, while being in a state of ecstasy and with closed eyes. The shaman ritual - kamlanie is the communication with this world through the shaman. During the ritual, a shaman dressed in a special suit brought himself and those present to a hypnotic state through singing and dancing under the rhythmic beats of a tambourine. The Kets believed that during this process, the spirits came to the shaman. In the process of kamlanie, the shaman imitated the voices of animals and birds, in the form of which spirits appeared to him. The shaman usually had an assistant - a netok — usually it was a relative, he helped the shaman to dress, served attributes, etc. Shamans performed a rite in their chum or in a chum of sick person, which began at sunset and lasted for several hours. The chants of the shaman reflected the main events of the shaman's journey to other worlds and his struggle with the evil spirits.

The shaman's ceremonial costume consisted of a parka, a breastplate (kuti) with embroidery of reindeer hair, symbolic colouring and metal pendants that contain spirit helpers, as well as a metal wand (tauks) in the form of a thin cane, culminating in several crossbars and a trident (instead of a shaman tambourine), shoes, a headband (sendada) or iron headgear. V.I. Anichin pointed out that shamans received costume elements and attributes in strict sequence. The peculiarity of shamanic clothes was the abundance of various pendants (iron, copper, tin) and drawings made with ochre on the skin and partially edged with reindeer hair. The main plot of the drawing, as a rule, was a stylized anthropomorphic or zoomorphic figure (in the centre of the parka), the moon and the sun (on the sides), figures of people (below). The shoes had a forked ornament, and there were also stylized trees and stars. The main attribute of the shaman was a tambourine with a beater, sometimes a second tambourine and a staff were additionally used.

The tambourine (khas) has a rounded shape covered with deerskin, on the outer side of which schematic anthropomorphic images were applied, as well as images 
of celestial bodies. The inner side of the tambourine - with a wooden handle and iron rods on which iron pendants were fixed, often in the form of expanding tubes (impersonation of arrows), images of bows, bird figurines (eagle, eider, swan). Shaman tambourines of Siberian peoples, including the Kets, were studied by E.D. Prokof'eva (Prokof'eva, 1961).

Until the beginning of the $20^{\text {th }}$ century the Kets had a special form of shamanism called "bear" shamanism, since the main spirit of the shaman was a bear, the owner of the underworld. Such shamans only carried out rites for the "lower world". The rite of bear shamans is comparable to the address of the Ket bangos to the "lower world". The bangos was a healer, a dreamer, a soothsayer and a sorcerer at the same time, and his gift was considered innate (but it could also be acquired by performing certain magical acts). The shaman and the bangos opposed to each other, and at times were at enmity with each other. Bangos actions could weaken the power of the shaman. Bangos "healed" people by spells, read fortunes, and with the help of amulets they predicted fate through a dream.

Shamans along with others took part in the fishery. The authority of the shaman was influenced by many factors: the results of his actions (the number of successful treatment cases, correct decisions, fulfilled predictions), his category and ideas about the stage of formation, as well as his personal qualities. It was believed that the shaman himself should be a good hunter and fisherman, a guardian of customs and norms of behaviour. Numerous examples refute the opinion of V.I. Anuchin that in the Kets' notions shamans "do not harm anyone". Obviously there is division of shamans into good and bad shamans. Bad shamans are those who committed malicious actions (refusal of treatment, incorrect treatment, etc.), incorrect actions in relation to a young shaman. E. A. Alekseenko notes that the workers of the village councils talked about the Kets' complaints about the moral pressure of the shamans, threats to bring illness or death to those whose actions were undesirable to them.

V.I. Anuchin in his works mentions one mythological plot, in which the Kets kill a shaman when his tambourine breaks. The Kets explain this by the fact that people tend not to remain without a shaman for a long time: with a broken tambourine, he became useless, and his death created the prospect to quickly obtain a successor.

The ritual actions of the Kets are based on certain beliefs associated with the dead, with respect to living people, ideas about death and the afterlife. The Kets isolated a certain vital substance called a soul, on which the life and death of a person depended. A human soul was represented in seven categories, but only a few of them have some 
information left. The main soul was atped, it is invisible, but if a person was absent in a dream, it meant his atped appeared (it was believed that it foreshadowed the absent appearance and was a sign of its longevity). Another category of the soul was called ulvei, it represents the shadow of a person, reflected in the water, in the pupil of another person, etc., so it can be seen. The most uncertain category was the kontorl, it often acts as a generalized concept of the soul, and in some cases it is equivalent to the concept of "bones" and a "skeleton" of a person. The totality of souls available to a person is called kedatped.

The soul could exist in the person himself and outside of him (separated with breath). During the illness of a person, his soul could get into the country of death to Khosedam and, in order to prevent this, the door of the dwelling with a seriously ill person was constantly kept closed. The task of the shaman who treated the patient was to find and return the main soul - atped.

According to the views of the Kets, after the death of a man, the ulvei first lived in a chum of the deceased for seven days, then wandered for seven years to places of former residence and collected his hair. It should be noted that the Kets never threw their hair away; the hair was collected and hung from young trees, so that a man could live and grow as a tree grows. After seven years, the ulvei could come to the relatives of the deceased in a shape of a bear they had harvested. And if the deceased was involved in the supernatural, she could have appeared in the form of a bear even earlier.

The Kets' notion of the world of the dead is represented in several variations: the underground country, the northern country in the lower reaches of the Yenisei and the western country where the sun sets. The northern and western sides were associated with the residence of the goddess Khosedam - it was her that the souls of sick people fell to. According to the Kets religious beliefs, not only the souls of the dead, but also the dead themselves enter the country of death. Some features of the funeral rite determine the idea of the location of the world of the dead.

They buried the dead necessarily near the river, on elevated places, dawns covered with coniferous forest. At the end of the $19^{\text {th }}$ and the beginning of the $20^{\text {th }}$ centuries, the Kets had two ways of burial: the most common was in the ground, and the other - in the air (as a rule, in a stump of a felled tree and on high platforms). Around the grave, first of all, they made a fire, "fed" the fire throwing pieces of food, tea and tobacco into it. The fire was kindled so that the deceased would not come after it to living relatives.

At burial, the orientation was strictly observed: a grave was dug exclusively from the west to the east, and a dead man was laid head to the east. Near the burial in the 
trees the clothes of the deceased hung, his personal belongings were left on the grave and near it. Leaving from the burial, people did not look back. The last person in the procession had to put a stick across the road to block the return of the deceased to the people.

Thus, the Ket religious ideology is presented to us in the form of beliefs and rituals that reflect the social and economic conditions of the ethnic group, which are different in their specifics and times. Animism was the basis of the Ket religious beliefs, where the supernatural beings that inhabited the world around them were divided into several categories depending on the form of interaction with humans. Later, the Kets' religious ideas were reflected in trade ideology, where the key goal was to achieve trade success, in shamanism and burial rites, where representatives of a religious cult helped a person to cope with natural phenomena and life events. In all these manifestations of the Kets' religious beliefs, remnants of ancient totemic and animistic ideas are still observed.

Summarizing the above material, it can be concluded that the specifics of the system of religious beliefs of both the Selkups and the Kets is based on economic and trade activities, or rather, on achieving success in it, since the trade activity was the main source of livelihood. Commercial beliefs are reflected in various prohibitions and rules of fishing activities, rites and signs, which in turn were the result of observing the life of animals and nature, as well as specific trade ethics. For both cultures the following features are characteristic: the preservation of animistic and ancient totemic religious beliefs, the idea of the world unity of the Upper, Middle and Lower worlds, understanding the role of a shaman as a mediator between the human world and the world of spirits, as well as the hereditary nature of receiving shamanic gift.

\section{References}

Alekseenko, E.A. (1967). Kety (istoriko-etnograficheskie ocherki) [Kets (historical and ethnographic essays)]. Leningrad, Nauka, 264 p.

Alekseenko, E.A. (1981). Shamanstvo u ketov [Ket shamanism]. In: Problemy istorii obshchestvennogo soznaniia aborigenov Sibiri (po materialam vtoroi poloviny $X I X$ - nachala XXvv.) [Problems of the history of the public consciousness of Siberian aborigines (based on materials from the second half of the $19^{\text {th }}$ - early $22^{\text {th }}$ centuries], 90-128.

Alekseenko, E.A. (1984). Etnokul'turnye aspekty izucheniia shamanstva u ketov [Ethnocultural aspects of studying Ket shamanism]. In: Etnokulturnye kontakty narodov Sibiri [Ethnocultural contacts of the peoples of Siberia]. Leningrad, 22-27. 
Anuchin, V.I. (1914). Ocherk shamanstva u eniseiskih ostiakov [Essay on shamanism in the Yenisei Ostyaks]. In: Sbornik Museia arheologii i etnografii [Bulletin of the Museum of Archeology and Ethnography], 2, 2.

Baidak, A.V. (2010). Predstavleniia sel'kupov o proishozhdenii zhizni po dannym mifologii i iazyika [Selkup views of life origin according to mythology and language data]. In: Izvestiya TPU [TPU Bulletin], 316 (6), 224-227.

Batashev, M.S., Makarov, N.P. (2018). Culture genesis of the peoples of the north of the Yenisei. Interaction of cultures (on the basis of the materials of Krasnoyarsk regional local lore museum). In: Zhurnal SFU. Gumanitarnye nauki [Journal of SibFU. Humanities \& Social Sciences], 11 (1), 4-18.

Baulo, A.V. (2018). Atribut sel'kupskogo shamana s izobrazheniem mamonta [Selkup shaman's paraphernalia with the image of a mammoth]. In: Vestnik arheologii, antropologii i etnografii [Bulletin of archeology, anthropology and ethnography], 3 (42), 128-132.

Baulo, A.V., Tuchkova, N.A. (2017). Mif o nyriaiushchih ptitsah, dostavshih zemliu, ustroistve mira i doroge v mir umershih: fol'klornoe nasledie Sel'kupov verhnei Keti v materialah Novosibirskoi etnograficheskoi ekspeditsii $1980 \mathrm{~g}$. [The myth of diving birds, got the land, the world order and the road to the world of the dead: the folklore heritage of the Selkup of Upper Ket in the materials of the Novosibirsk ethnographic expedition of 1980]. In: Uralo-altayskie issledovaniya [Ural-Altaic Studies], 1 (24), 7-18.

Belich, Ig.V., Belich, Ir.V. (1997). K voprosu o kul'tovyh mestah tazovskih sel'kupov [On the question of religious places Taz Selkup]. In: Vestnik arheologii, antropologii $i$ etnografii [Bulletin of archeology, anthropology and ethnography], 1, 99-112.

Bobrova, A.I., Toroshchina, N.V. (2013). Antropomorfnye lichiny iz mogil'nika Bederovskii Bor II [Anthropomorphic masks from burial ground Bederevsky Bor II]. In: Vestnik TGU. Istoriya [TSU Journal. History], 2 (22), 18-21.

Bychkov, Iu.A. (2012). Ptitsa kak simvol religiozno-mifologicheskoi sistemy v traditsionnoi kul'ture etnosov Sibiri [Bird as a symbol of religion and mythology in traditional culture of Siberian ethnic groups]. In: Vestnik NVGU [NVSU Bulletin], 3, 57-60.

Bykonia, V.V. (2013). Nekotorye tendentsii formirovaniia slovarnogo fonda sel'kupskogo iazyka [Some tendencies of Selkup vocabulary formation]. In: Vestnik TGPU [TSPU Bulletin], 3 (131), 62-67.

Chundina, L. (1991). Istoriya srednego Priobya v epohu rannego srednevekovia (relkinskaya kultura) [History of the middle $\mathrm{Ob}$ in the early middle ages]. Tomsk, Tomskii universitet, $179 \mathrm{p}$. 
Donner, K. (2008). Y samoedov v Sibiri [Among the Samoyeds in Siberia]. Tomsk, Veter, $176 \mathrm{p}$.

Dul'zon, A.P. (1968). Ketskii iazyk [Ket language]. Tomsk, Izdatel'stvo Tomskogo universiteta, $636 \mathrm{p}$.

Dolgih, B. (1934). Kety. [Kety]. Irkutsk, 134 p.

Findeisen, H. (1937). The Kets: research on a North Siberian people [Die Keto. Forschugen uber ein nordsibirischen Volk]. In: Sinica Sonderausgabe, 1, 52-68.

Galeeva, N.F. (2016). Traditsionnaia i nauchnaia interpretatsiia predmetov shamanskogo kul'ta Sel'kupskogo naroda iz sobranii MVK im. I. S. Shemanovskogo [Traditional and scientific interpretation of the objects of the Selkup shaman cult from the collections of museum and exhibition complex named after i. s. Shemanovsky]. In: Nauchnyi vestnik Iamalo-Nenetskogo avtonomnogo okruga [The bulletin of YamaloNenets Autonomous Region], 3 (92), 54-57.

Gemuev, I.N. (1980). K istorii sem'i i semeinoi obriadnosti sel'kupov [To the history of the family and family rituals of the Selkup]. In: Etnografiia Severnoi Azii [Ethnography of North Asia]. Novosibirsk.

Gemuev, I.N., Pelih, G.I. (1993). O pogrebal'noi obriadnosti sel'kupov [About the funeral rites of the Selkup]. In: Asta Ethnographica Hungarica [Asta Ethnographica Hungarica], 38(1-3), 287-308.

Golovnev, A.V. (1995). Govoriashhie kul 'tury: tradicii samodiicev i ugrov [Talking cultures: traditions of Samoyedians and Ugrians]. Ekaterinburg.

Gohman, I.I., Bashlai, A.G., Benevolenskaia, Iu.D., Davydova, G.M., Zhomova, V.K. \& Hit, G.L. (1982). Ketskii sbornik. Antropologiia, etnografiia, mifologiia, lingvistika [Ket collection. Anthropology, ethnography, mythology, linguistics]. Leningrad, Nauka, 256 p.

Ioki, A.J. (1946). Indo-Chinese loan words in Samoyedic [Indochinesische Lehnworter im Samojedischen]. In: FUF, 29, 202-221.

Karger, N.K. (1934) Ketskii iazyk [Ket language]. In: Iazyki i pis'mennost ' narodov Severa [Languages and script of the peoples of the North]. Moscow.

Karzanova, G.A. (2016). Mamont v mifologii sel'kupov [Mammoth in Selkup mythology]. In: Nauchnyi vestnik Iamalo-Nenetskogo avtonomnogo okruga [The bulletin of Yamalo-Nenets Autonomous Region], 1 (90), 19-22.

Kazakevich, O.A. (2018). Videnie sel'kupskogo shaman [A vision of a Selkup shaman]. In: Antropologicheskii forum [Anthropological forum], 38, 195-208.

Kazakevich, O.A., Helimskii, E.A. (2002). Ketskii iazyik, In Iazyki narodov Rossii. Krasnaia kniga [Languages of the peoples of Russia. Red Book], 93-98. 
Kim-Maloni, A.A., Tereshhenko, A.V. (2018). Lingvokul'turologicheskii analiz toponimov $\mathrm{v}$ sel'kupskoi mifologii (na material shamanskogo puteshestviia po miru) [Linguoculturological analysis of toponyms in selkupsky mythology (on the material of shamansky traveling in peace)]. In: Iazyk i kul'tura. Sbornik statei XXVIII Mezhdunarodnoi nauchnoj konferencii [Language and culture. Collection of articles of the XXVIII International Scientific Conference], 231-236.

Kim, A.A. (2018). Antropomorfnye komponenty v sostave imen sobstvennyh v fol'klore narodov Obsko-eniseiskogo areala [Anthropomorphic components in the composition of the names of the own peoples of the Ob-enisei area own in the folklore]. In: Vestnik Tomskogo gosudarstvennogo pedagogicheskogo universiteta [Tomsk State Pedagogical University Bulletin], 8 (197), 74-78.

Koptseva, N.P. (2012). Korennye malochislennye narody Severa i Sibiri v usloviiah globalnyh transfomatsyi [Small indigenous peoples of the North and Siberia in the context of global transformations]. Krasnoyarsk, SibFU, 638 p.

Kreynovich, E.A. (1968). Glagol ketskogo iazyka [Ket verb]. Leningrad, Nauka, $283 \mathrm{p}$.

Maroshi, V.V. (2018). Mezhdu mifom i antropologiei: kety v sovremennoi russkoi literature [Between myth and literary anthropology: Ket ethnicity in contemporary Russian literature]. In: Sibisrkii filologicheskii zhurnal [Siberian Journal of Philology], 4, 95-107.

Mogilnikov (1929). Reka Chulym ot ust' ja Kii do vpadenija v reku Ob': locmanskaja karta [Chulym river from the mouth of the Kiya to the confluence of the Ob river: pilot map]. Omsk, electronic resource.

Nikolaev, R.V. (1985). Fol'klor i voprosy jetnicheskoi istorii ketov [Folklore and questions of Kets Ethnic History]. Krasnojarsk, Izdatel'stvo Krasnoiarskogo universiteta, $127 \mathrm{p}$.

Ozheredov, I.I., Ozheredova, A.I., Kirpotin, S.N. (2015). Selkup idols made of tree trunks and found on the Tym River. In: International Journal of Environmental Studies, 72, 3, 567-579.

Ozheredov, Y.I., Ozheredova, A.I., Kulizhskiy, S. (2014). Trees in sacral and utilitarian practice: the value of nature and ecology in the life of the Selkups. In: International Journal of Environmental Studies, 71, 5, 761-767.

Pankratova, L.V. (2011). Images in bronze from the Sarovka ritual complex: reconstructing semantics. In: Archaeology, Ethnology and Anthropology of Eurasia, 39 (1), 82-91. 
Pelikh, G.I. (1972). Proishozhdenie sel kupov [The origin of the Selkup]. Tomsk, Izdatel'stvo Tomskogo universiteta, $424 \mathrm{p}$.

Pelih, G.I. (1980). Materialy po sel'kupskomu shamanstvu [Materials about Selkup shamanism]. In: Etnografiia Severnoi Azii [Ethnography of North Asia]. Novosibirsk.

Pelih, G.I. (1998). Sel’kupskaia mifologiia [Selkup mythology]. Tomsk, Izd-vo Tom. gos. un-ta, 79 p.

Poliakova, N.V. (2016). Obraz ognia v iazykovoi kartine mira Sel'kupov [Figure of fire in the worldview of Selkups]. In: Vestnik TGPU [TSPU Bulletin], 6 (171), $54-57$.

Poliakova, N.V. (2012). “Osobye mesta” v kartine mira sel'kupskogo etnosa ["Sacred places" in the worldview of the Selkups]. In: Vestnik TGPU [TSPU Bulletin], 10 (125), 85-88.

Poliakova, N.V. (2014). Ob“ektivatsiia lesa v iazykovoi kartine mira sel'kupskogo etnosa [Objectivization of forest in the worldview of selkups]. In: Vestnik TGPU [TSPU Bulletin], 10 (151), 76-80.

Poliakova, N.V. (2014). Ob“ektivatsiia reki v iazykovoi kartine mira sel'kupskogo etnosa [Objectivization of river in the linguistic world-view of the selkup ethnos]. In: Tomskiy zhurnal lingvisticheskih $i$ antropologicheskih issledovaniy [Tomsk Journal of Linguistics and Anthropology], 2 (4), 29-33.

Poliakova, N.V. (2015). Ob“ektivatsiia predstavlenii o «Nizhnem mire» V sel'kupskom iazyke v sopostavlenii s russkim [Objectification of understanding of "Lower world" in the Selkup langauge in comparison with the Russian language]. In: Vestnik TGPU [TSPU Bulletin], 4 (157), 56-61.

Poliakova, N.V. (2015). Ob“ektivatsiia prirodnyh iavlenii v sel'kupskom i russkom iazykah v sopostavitel'nom aspekte [Objectivization of natural phenomena in the selkup and russian languages in comparative aspect]. In: Vestnik TGPU [TSPU Bulletin], 10 (163), 69-73.

Poshekhonova, O.E., Afonin A.S., Kisagulov, A.V., Gimranov, D.O., Nekrasov, A.E., Iakimov, S.A., Bazhenov, A.I. (2015). Nekotorye elementy pogrebal'nogo obriada severnyh sel'kupov po dannym paleoekologicheskih issledovanii [Certain elements of burial rite of Northern Selkup according to palaeoenvironmental studies]. In: Vestnik arheologii, antropologii i etnografii [Bulletin of archeology, anthropology and ethnography], 4 (31), 165-174.

Prokof'ev, G.N. (1940). Etnogoniia narodnostei Ob'-Eniseiskogo basseina (nencev, nganasanov, encev, sel'kupov, ketov, hantov i mansi) [Ethnogony of the Ob-Yenisei 
basin ethnic groups (Nenets, Nganasans, Ents, Selkup, Kets, Khanty and Mansi)]. In: Sovetskaia etnografiia [Soviet ethnography], T. 3.

Prokof'eva, E.D. (1949). Kostium sel'kupskogo (ostiako-samoedskogo) shaman [The costume of the Selkup (Ostyak-Samoyed) shaman]. In: SMAE [SMAE], T.XI, Leningrad.

Prokof'eva, E.D. (1952). K voprosu o social'noi organizacii sel'kupov (rod i fratriia) [To the question of the Selkup social organization (genus and phratry)]. In: Trudy IE. Novaia seriia [Proceedings of IE. New series]. Moskow, Leningrad, T. XVIII, 88-107.

Prokof'eva, E.D. (1961). Shamanskie bubny [Shaman tambourines]. In: Istorikoetnograficheskii atlas Sibiri [Historical and Ethnographic Atlas of Siberia], 435-490.

Prokof'eva, E.D. (1976). Starye predstavleniia sel'kupov o mire [Old ideas of the Selkup about the world]. In: Priroda i chelovek v religioznyh predstavleniiah narodov Sibiri i Severa [Nature and man in the religious ideas of the peoples of Siberia and the North]. Leningrad.

Prokof'eva, E.D. (1977). Nekotorye religioznye kul'ty tazovskih sel'kupov [Some religious cults of the Taz Selkup]. In: SMAE [SMAE], T. XXXIII Leningrad.

Rozov, N.S. (1958). Antropologicheskii sostav drevnego naseleniia Srednei Obi (sel'kupov) [Anthropological composition of the ancient population of the Middle $\mathrm{Ob}$ (Selkup)]. In: Uchenyie zapiski Tomskogo universiteta [Scholarly notes of the University of Tomsk], 32.

Ryndina, O.M., Kolesnikova, S. Ju., Kulemzin, V.M. (2018). Vremia i prostranstvo v samodiiskoi tradicii: kalendar' i narta [Time and space in self-tradition: calendar and narta]. In: Vestnik Tomskogo gosudarstvennogo universiteta. Istoriia [Tomsk State University Bulletin. Story], 56, 143-150.

Sidorova, T.A. (2017). Etnokul'turnaia situatsiia basseina reki Tym XIX — pervoi treti XX vekov [The etno-cultural situation of the Tym river basin of the $19^{\text {th }}$ - first third of $20^{\text {th }}$ centuries]. In: Sbornik materialov XIII vserossiiskoi nauchnoi konferentsii "Voprosy istorii, arheologii, politicheskih nauk i regionovedeniia" [Proceedings of the XIII all-Russian scientific conference "Questions of history, archeology, political science and regional studies"], 272-278.

Simchenko, Ju.B. (1965). Tamgi narodov Sibiri XVII veka [Tamgas of the peoples of Siberia of the $17^{\text {th }}$ century], Moskow.

Stepanova, O.B. (2006). "Zlaia” ili "dobraia": k voprosu o glavnom mifoligicheskom obraze sel"kupov ["Evil" or "Good": on the question of the main mythological image of the Selkup]. In: Omskii nauchnyi vestnik [Omsk bulletin], 8, 52-55. 
Stepanova, O.B. (2007). Mifologicheskii obraz materi-dereva v traditsionnom mirovozzrenii sel'kupov [The mythological image of the mother tree in the traditional worldview of the Selkups]. In: Arheologiia, etnografiia $i$ antropologiia Evrazii [Archaeology, Ethnology and Anthropology of Eurasia], 3, 115-118.

Surkov, D.A. (2012). Amulety i oberegi v kontekste magicheskih predstavlenii aborigennyh narodov zapadnoi Sibiri [Charms and guarding talismans in magical views of western Siberia aboriginal peoples]. In: Vestnik TGU [TSU Journal], 362, $100-102$.

Tereshchenko, A.V. (2014). Lingvisticheskaia priroda i osobennosti funktsionirovaniia stilisticheskogo priema «metamorfoza»: na primere sel'kupskogo prozaicheskogo fol'klora i mifov narodov mira [Linguistic nature and functioning pecularities of the stylistic device of "metamorphosis": based on the material of Selkup prose folklore and world mythology]. In: Vestnik KemGU [Bulletin of KemSU], 4-2 (60), 194-199.

Tereshchenko, A.V. (2014). Religiozno-kul'tovye topoleksemy v sel'kupskom iazyke [Religious-cult topolexemes in the Selkup language]. In: Vestnik TGPU [TSPU Bulletin], 4 (145), 72-79.

Tereshchenko, A.V. (2014). Stilisticheskii priem «metamorfoza» i osobennosti ego reprezentatsii $\mathrm{v}$ sel'kupskih skazkah i mifah narodov mira [Stylistic device "metamorphosis" and specifics of its representation in the selkup tales and world myths]. In: Filologicheskie nauki. Voprosyi teorii i praktiki [Philology. Theory and practice], 10-1 (40), 180-186.

Toporov, V.N., Uspenskii, B.A. (1968). Predislovie. Kety, ih iazyk, kul'tura, istoriia [Preface. Kety, their language, culture, history]. In: Ketskii sbornik. Lingvistika [Ket collection. Linguistics]. Moskow.

Toroshchina, N.V., Bobrova, A.I., Shatilov, M.B. (2015). Metallic masks from the River Tym. In: Bylye Gody [The other years], 36 (2), 238-244.

Tsai, A.V., Rusak, U.E., Efanova, E.N. (2016). Kul'tura i istoriia sel'kupskogo naroda [Selkup folk culture and history]. In: Sbornik materialov II Vserossiiskoi nauchno-prakticheskoi konferentsii "Sever Rossii: strategii i perspektivyi razvitiya" [Proceedings of the II All-Russian scientific and practical conference "The North of Russia: strategies and prospects of development'], 244-248.

Tuchkova, N.A. (2018). Neskazochnaia proza v folklore Sel'kupov: predaniia i bylichki [Non-fairy-tale prose in the Selkup fol'klore: legends and little heroic epic ballades]. In: Iazyki i folklor korennyh narodov Sibiri [Languages and folklore of indigenous peoples of Siberia], 1 (35), 97-105. 
Vainshtein, S.I. (1951). K voprosu ob etnogeneze ketov [On the issue of Kets ethnogenesis]. In: Kratkie soobshcheniia instituta etnografii AN SSSR [Brief summaries of the Institute of Ethnography of the Academy of Sciences of the USSR], 13, 3-7.

Vainshtein, S.I. (2015). Kety Podkamennoi Tunguski [Kets on the Podkamennaia Tunguska River]. Krasnoyarsk, Sibirskie promysly, 175 p.

Vajda, E. (2010). Yeniseian, Na-Dene, andHistoricalLinguistics. In: Anthropological Papers of the University of Alaska, 5, 100-118.

Vdovin, I.S. (1976). Priroda i chelovek v religioznyh predstavleniiah narodov Sibiri $i$ Severa: vtoraia polovina XIX - nachalo XX v. [Nature and man in the religious beliefs of the peoples of Siberia and the North: the second half of the $19^{\text {th }}$ - early $20^{\text {th }}$ centuries]. Leningrad, Nauka, 330 p.

Verner, G.K., Nikolaeva, G.H. (1993). Ketskii iazyik [Ket language]. St. Petersburg, Prosveschenie, $143 \mathrm{p}$.

Verner, G.K., Nikolaeva, G.H. (1996). Bukvar': dlya 1-go kl. ketskoy shk. [ABC-book for 1st grade of a Ket school]. St. Petersburg, Prosveschenie, 143 p.

Zhuravskii, A.V., Kazmina, O.E., Tishkov, V.A. (2009). Narody Rossii: atlas kultur $i$ religii [Peoples of Russia: atlas of cultures and religions]. Moscow, Dizain. Informatsiia. Kartografiia, 320 p.

\section{Религия селькупов и кетов в историческом и культурном генезисе}

Ю.Н. Авдеева, К.А. Дегтяренко, Д.С. Пчелкина, К.И. Шиманская, Н.П. Копцева, А.А. Шпак Сибирский федеральнылй университет Россия, 660041, Красноярск, пр. Свободньй, 79

$\overline{\text { Статья посвящена исследованию генезиса религиозных представлений кетской }}$ и селькупской этнокультурных групп в историческом и культурном контексте. На основе этнографического и лингвистического материала в статье дается описание современного состояния религии и культуры кетов и селькупов, делается аналитический обзор классических и современных исследований, отражающих динамику развития религиозной идеологии на территориях проживания данных этнических групп. Несмотря на официальную христианизацию, и кетьл, и селькупь на протяжении многих лет сохраняют свои традиционные космологические и мировоззренческие представления. Для их религиозной идеологии характерно сосуществование различных по времени возникновения и специфике 
верований и обрядов, которые отражают природные, бытовые, хозяйственные и соччиальные условия жизни этнических общностей. К ключевым проявлениям религиозной идеологии авторы относят представление о трехчастной структуре мироздания, анимистические и древние тотемические верования, развитую промысловую идеологию, шаманизм, погребальные обряды и фольклор.

Ключевые слова: кеты, селькупы, коренные малочисленные народы севера, религия, религиозные культы, шаманизм, промысловая идеология, анимизм, тотемизм.

Исследование выполнено при поддержке $А O$ «Востсибнефтегаз» в рамках реализаиии проекта по выполнению научно-исследовательских работ «Возрождение эвенкийского языка: создание первой циирровой аудиотеки эвенкийского языка».

Научная специальность: 24.00.00 - культурология. 